\title{
"It All Started with the Amish": Reflections on a Career in Iowa History
}

\section{DOROTHY HUBBARD SCHWIEDER}

EDITORS' INTRODUCTION: It is the rare historian who can claim to have rediscovered and reinvigorated an entire field of history. Dorothy Hubbard Schwieder (November 28, 1933-August 13, 2014) was one of those scholars. Frequently lauded as the "dean of Iowa history," she revitalized a long-declining field, making it lively and relevant and adding a fresh emphasis on social history. Her contributions also extended far beyond her own work-a colleague once further christened her the "den mother" of Iowa history for her generous efforts to support colleagues in the field and nurture future generations of Iowa history scholars.

Dr. Schwieder accomplished this from her position in the History Department at Iowa State University (ISU), where she began as a parttime instructor in 1966 and retired as University Professor in 2000. She was the first woman to hold a faculty position in the department and the first to achieve the rank of full professor. She remains the only member of the history faculty to be named a University Professor, an uncommon honor reserved for long-time faculty members who have acted as agents of significant change at ISU. The quintessential "complete academic," Schwieder earned this title in all phases of the professor's role: she was a prolific and award-winning scholar; a rigorous, popular teacher; and she served the people of Iowa through radio and television appearances, work on boards and commissions, and speeches and presentations throughout the state.

THE ANNALS OF IOWA 75 (Winter 2016). (C) State Historical Society of Iowa, 2016. 
What follows is her presentation for the spring 2013 annual banquet of ISU's Phi Alpha Theta history honors society. The History Department chose that occasion to designate the Dorothy Hubbard Schwieder Seminar Room in recognition of her nearly 50 years of accomplishments and contributions to the field, the department, and Iowa State University.

\section{- Pamela Riney-Kehrberg and David W. Schwieder}

THANK YOU for inviting me to speak to you this evening. I'm honored to be here. I think the best part of the invitation was: "We would like you to talk about your research, past and present." In other words, talk about your own work! It doesn't get any better than that. I would like to share with you a little about my own professional history and, in the process, tell something about the history of the ISU History Department. I will focus on three of the most important research projects I undertook, and then I'd like to conclude with some reflections on all of this.

OVER A DECADE has gone by since I retired from Iowa State, though it doesn't seem that long. I consider it a privilege to have been a part of the history faculty here for 34 years. But, as one often hears, "things were a bit different back then." In many ways, academia was less formal and less structured. It probably seems odd to hear this today, when careers are such an institutionalized affair, but much of my own career came about by accident or just plain serendipity.

I started at Iowa State in the mid-1960s as a graduate student in the history master's degree program. Iowa State hadn't yet experienced the tremendous academic growth of the 1960s, and the fields of history, government, and philosophy were combined into one department. Our wonderful secretary, Carole Kennedy, was from Oklahoma, and at first it took some time for her to say, "History, Government, and Philosophy." But she quickly shortened that!

The department was located on the third floor of Beardshear Hall then - with no elevator at that time. The graduate students' desks - as well as several faculty offices - were actually up another flight in an area with no windows and no air conditioning. 
After Ross Hall was completed in 1973, the fourth floor of Beardshear was taken over by the Psychology Department's experimental lab. That included experiments with rats. Air conditioning was then added for those delicate little creatures-apparently historians were presumed to be a hardier breed.

During that time, I was very fortunate in that the department often needed someone to teach a course or two on a part-time basis. Since I was the oldest graduate student, I was approached to do that. At first, I taught a course in American economic history and then, for a few years, I taught sections of the introductory U.S. history survey course. At that time, Iowa State was on the quarter system, and so national foundations, national expansion and internal conflict, and national consolidation and world power constituted a yearly sequence. The first course was my favorite and the last was my least favorite.

After I finished my master's degree, I stayed on, and my first few years in the department were spent as a part-time, temporary instructor. I never knew from quarter to quarter if I would have a teaching position. Despite my temporary status, the chair, Louis Geiger, had taken a personal interest in me and had decided that Dorothy Schwieder needed to begin work on a Ph.D. The catch: I would have to go somewhere else for the degree, as our department did not offer doctoral study in the 1970s. So, the pressure began: "Dorothy, you need to apply for a faculty improvement leave so you can go somewhere for a Ph.D." Then he would add, "We need to find out how good you are." I was always tempted to ask: "Well, can't you tell?" But I decided on the University of Iowa, and I was awarded the leave in 1977. It was a 145-mile commute to Iowa City, one way, for two years. I started in 1977 and received the doctoral degree in 1981, studying with the formidable and distinguished Linda Kerber. For much of that time I was still teaching full time in the ISU history department.

During my time in the department, I taught many different courses: American economic history, history of American women, nineteenth-century American social history, two graduate seminars in the Agricultural and Rural Studies program, both sections of the American history survey, and Iowa history. The latter course, Iowa history, became my mainstay. It was the course that I taught most frequently and the area in which I ultimately did most of my research. 


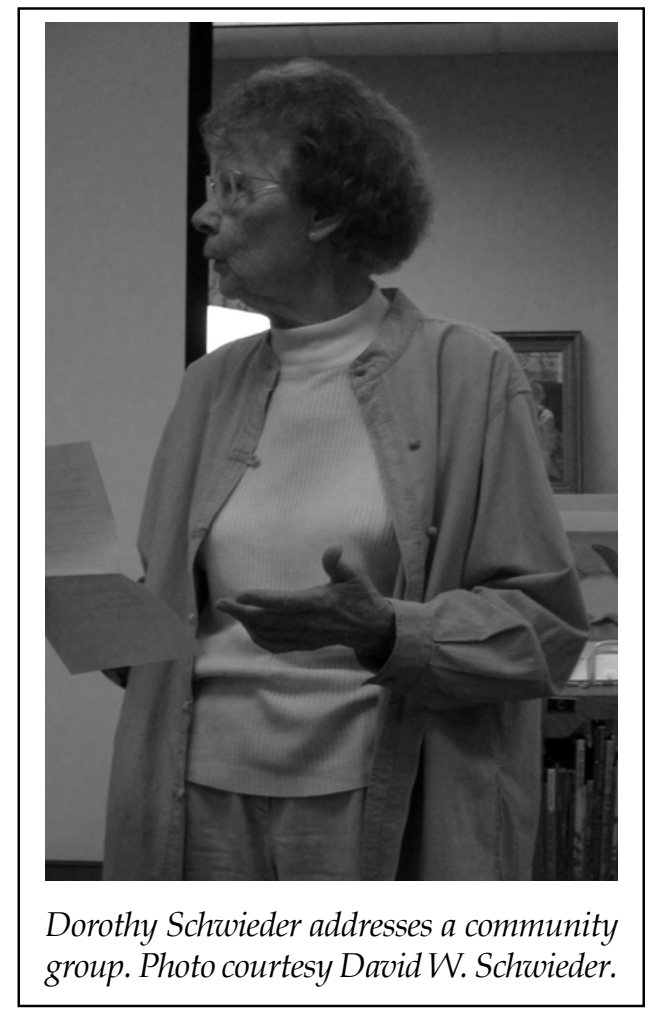

I INITIATED THE COURSE in Iowa history in the spring of 1970. Being interested in communitarian societies - I had done my master's thesis on the Hutterites, a communal group in South Dakota - I had started researching the Old Order Amish in Iowa and, in the process, began to read about Iowa's early history. It made for interesting reading.

One day the idea struck me: What about a course in Iowa history? As far as I knew, the course had never been taught at Iowa State. But since ISU was a land-grant school, a course in state history seemed appropriate. I headed off to talk to the chair of the department. The chair by that time was Walter Rundell, a Texan. As a Texan, Rundell believed that state history was important. He suggested that I put together a statement of how I would approach the class and what resources were available. That was on a Monday. On Friday afternoon I was back in his office. He looked at the prospectus and said, "How soon can you start?" 
This, I think, is an example of the serendipity that I referred to earlier. As a proud Texan (is there any other kind?), Walter Rundell was well aware of Texas's unique history, and it was selfevident to him that state history mattered. But I think it's far less likely that someone from a more self-effacing state or region like Iowa or the Midwest would have seen the value of such a course. However, a few of my colleagues did have a less positive reaction. After all, as everyone knew then, state history had little value for professionals. State history was only for untrained historians who enjoyed researching local and minor topics with little broader importance.

Once the Iowa history class was in the course listings for spring quarter, 1970, I started promoting it. I think I must have been the first person to do that at ISU. I was teaching several sections of survey and mentioned it in those classes. I went around to a number of advisers outside of history, telling them why I felt the class would have value for their students. I think it's fair to say I really pounded the pavement, and while many were surprised, the visits created considerable interest in the course.

I quickly discovered that ISU students enjoyed learning about the history of their state. My classes always had a few students from out of state, but the great, great majority were Iowans. From the beginning of the course, my family and I-husband Elmer and two small children - traveled around Iowa to see many sites and attend various events: the Harvest Festival at Living History Farms; Nordic Fest in Decorah; the State Historical Museum in Des Moines; and various Mississippi River communities. We met people from all over Iowa, and I began to gain a better understanding of the culture of the state.

It didn't take long to begin to see the research possibilities. Iowa had a fine tradition of strong state history publications, including the Iowa Journal of History and Politics, the Annals of Iowa, and the Palimpsest. It was one of the few states that had three separate state history journals. And there were many series such as the Iowa Biography series, the Applied History series, and the Iowa Economic History series. Two multi-volume histories of Iowa also existed. There was obviously no shortage of scholarly literature, but most of it was political and economic history. There simply wasn't much on the history of women or ethnicity and 
immigration or on communities. There was material on railroad development, steamboating on the Mississippi River, and major industries like meatpacking. It probably sounds a bit odd now, but at that time the subjects that would form the core of the "new social history" were little apparent.

Fortunately, that began to change, although slowly. I still remember what a pleasure it was to get a copy, in 1974, of Glenda Riley's book, Iowa Frontierswomen. Another helpful book was Clarence Andrews's Literary History of Iowa. So, the research started. I was fortunate that the state library and archives were only 30 miles away in Des Moines. The state and federal censuses and the state's newspaper archives were both housed there. This was an important point, sometimes overlooked; research materials were close at hand. I had a husband and two young children. I couldn't travel to the Roosevelt Library or the Huntington Library. But I could get my children ready for school, spend five hours in Des Moines, and return to Ames before they arrived home. This is a part of the story of women in the fifties and sixties that is often overlooked.

THE FIRST MAJOR RESEARCH PROJECT was one of the most memorable of my entire professional career. In 1965 there had been a controversy in Iowa over the state's educational policies for the Old Order Amish. At the time, the Amish had two large settlements in eastern Iowa. Since my master's thesis had been on the Hutterites, I thought it would be interesting to do a comparative study of the two groups. I quickly discovered that there was little or no scholarly material on the Amish in Iowa. There was the federal census and one book on the Iowa Mennonites (which included limited material on the Amish) published in 1939.

So, how to find information about the Old Order Amish? There seemed to be only one way: Go to the source itself and visit the Amish communities. First, there was the matter of gaining access to the Amish community. Fortunately, ISU has a Cooperative Extension Service, and the county agent for Washington County - which contained the largest Amish community - was very helpful. The agent, Jim Frier, didn't know any of the Amish, but like a good Extension person, he did know his community resources. So, he knew the people who did know the Amish. 
Also, he was feeling a bit guilty that he had not really made contact with any Amish residents, so he asked a local person to set up some interviews. Marie Jackson, a bank employee, knew the Amish well. She drove out to their farms to inquire about a meeting; the result was four appointments with Amish families.

By that time, my husband, Elmer, an ISU faculty member and sociologist, had also became interested in the Amish, so we were able to team up on this endeavor. On a beautiful spring day, Elmer and I drove to Kalona and spent a full day, along with Marie Jackson and Jim Frier, visiting four Amish farmsteads. What an interesting experience! We met Amish men, women, and children. Each family had some food waiting for us. Although not outgoing by "English" standards, none were reluctant to answer our questions and tell us about their farming methods, their religious views, and their social lives.

We knew that the Amish would not appreciate the use of modern contrivances like tape recorders or cameras, and even notes seemed a bit obtrusive in that setting. So, we listened carefully to their comments. As we left one farm, the farmer commented, almost casually, "Oh, you might like to meet my brother who lives down the road. He's a bishop." The door was swinging open, and we made many, many more visits to the Kalona area, as well to as Buchanan County, and also to a new Amish settlement near Milton. Each time was the same: We listened intently, and as soon as we were in the car heading home, Elmer drove as I scribbled down everything we could remember.

Several experiences particularly stand out from these visits. One of the Amish families we spent much time with was headed by Toby Miller and his wife, Ruth. Toby was the perfect image of the Amish patriarch-distinguished manner and long, flowing, white beard. They were always welcoming. We soon learned that Toby and Ruth had ten sons-no daughters! One day, Elmer asked, "Ruth, how many grandchildren do you have?" "Fiftyeight." My husband, who could be quite irreverent, muttered to me, "I'd have to give them numbers."

In some ways, the Amish seemed as interested in us as we were in them. The Amish are very traditional people, and they were a little confused when Elmer, the male, asked about family roles, and I asked about agricultural acreages and practices. 
The Old Order Amish project really marked the beginning of a long career doing oral history. In fact, the research with the Amish came before oral history was a common term. Along with social history, this methodological innovation awaited development in the future. From that point on, oral history was a part of almost all of my research projects.

WHILE THE AMISH PROJECT extended over a number of years, eventually culminating in the first history of Iowa's Old Order Amish, A Peculiar People, other research interests also began to arise. Another project first originated in my dissertation, which focused on coal mining in Iowa. The state had a rich history in this area; driven by the need to service the railroad industry and its steam engines, Iowa had enjoyed a thriving mining industry.

During the course of that work, I had happened to meet the state mine inspector, Dean Aubrey. I was teaching Iowa history and was asking him some questions about coal mining history. He knew he was about to retire, and he desperately wanted someone to begin working on the history of Iowa's coal mining industry. When I met him that day and started asking questions about coal mining, he thought he had a real live one. For the next several years, he and the assistant mine inspector, Marv Ross, kept sending me names of former coal miners with a note: "You should really interview this person." If nothing else, the ethnicity of the miners intrigued me as much as the industry itself.

The methodology was predictable: Here again, oral history was indispensable, along with state mine inspectors' reports; newspapers from coal mining communities such as Albia; data from both state and federal censuses; photographs and location maps of mines (all available in Des Moines). Many of the interviews were memorable. Patterns quickly emerged. Men loved to talk about strikes and violence, and they remembered clearly the mine layouts, mining processes, and the daily work routine. The strikes and violence also were usually covered in the newspapers and mine inspectors' reports. Interviewing the women was an entirely different matter. First, whenever I wrote to a wife of a retired coal miner, the man automatically assumed that I wanted to interview him. I learned to carefully state that I was interested in the domestic side of their lives, what went on in the home, 
what work the wives had to do. Still, the man often greeted me at the door by asking, "Well, what do you want to know?"

One of my favorite memories was my interview with Katy DeGard. She was second-generation Italian American and had married John DeGard, a coal miner. Katy's father had been what was called the social boss in the Seymour community. The social boss was just that. He helped other immigrants find work in the mines; he helped them apply for citizenship; and he sometimes helped them find a wife. When I arrived at their house, I had two things to do: First, convince John that although I knew he had a great deal of information and I would love to talk to him another time, I really wanted to interview Katy. Second, I had to convince Katy that she had something to say. Her initial response had been typical of many of the women: "Well, I didn't do anything that was important."

By then I had discovered a good question to get things started: "Tell me about your day. Starting first thing in the morning, what did you do?" Very quickly the women could see that their role had been indispensable. Their stories recited a tremendous amount of work - meal preparation (baking bread several times a week), tending a large garden, washing clothes (including greasy pit pants) on a scrub board, caring for children. In addition, many took in boarders. These men had to be fed, had to have lunches to take to the mines, and had to have their clothes laundered. Because many of the boarders were also from Italy, they were often treated like family.

The interview with Katy DeGard was wonderful, and she obviously enjoyed it. I was using a tape recorder for these sessions, and I had to plug it into the light that hung from the ceiling. The tape recorder was placed on a chair in the middle of the room. At first, Katy had her chair pulled back a ways, but as the interview progressed, she inched closer and closer to the microphone. Sometime near the end of the interview, the phone rang. John DeGard - who was not going to miss any of this - was sitting around the corner in the kitchen. The phone rang several times and John said, "Well, aren't you going to answer it?" It was obvious that that was Katy's job. But by this time, Katy was well into her story and feeling good about the whole thing. "Answer it yourself," she said - and her very surprised husband did! All 
told, I interviewed 45 families or individuals, and transcribed all 45 interviews myself.

For the dissertation, census data proved invaluable: days worked, number of children in family, number of boarders in family, place of birth, place of birth of parents, and so on. Processing the census data was another matter. I had never had a course in statistics or anything like SPSS. But one of my committee members believed it would be a good idea. He himself had never done any type of quantitative work, so he couldn't help either. I was really flying blind, and so the frustration began. Fortunately I got a great deal of help from John Kolp, a friend from ISU who was later head of the political science statistics lab at the University of Iowa. Somehow I managed to blunder my way through the whole process and ended up with a chapter using census data. I must admit, however, that my dissertation (and the book that eventually came out of it) were much the better for this. So, just a note for graduate students: sometimes it is worthwhile to follow your adviser's advice!

By that point - the early 1980s - oral history was becoming more respectable. However all my sources proved indispensable - in particular, the other sources provided a way to check on the veracity of memory in the oral histories. The study included material on the mining process itself, a chapter on the history of the United Mine Workers, a chapter on the social life of mining families, and the census data chapter. Finally, I have to mention one more perk of this research effort-a trip down into a working coal mine.

THE THIRD PROJECT I would like to talk about was the study of Buxton. About the time I was finishing my dissertation, there was an opportunity to be involved in a research project on a highly unusual coal mining community called Buxton, located in southern Iowa. Owned by the Chicago and North Western Railroad, Buxton was a company town built to provide coal for the railroad's locomotives. During the town's heyday - circa 1910over half the population (of 5,000 people) were African Americans. This was highly unusual for Iowa, but even more unusual was the fact that black businesspeople and professionals enjoyed an unusual degree of autonomy and respect. 
This project followed the same approach as my previous works but was set up very differently. ISU had the opportunity to apply for a federal grant to do historical and archaeological research on a coal mining community - Buxton - and this project involved myself, a sociologist, and an anthropologist. The grant was awarded in 1980, and I served as project administrator. At the time, Buxton had been defunct for some 55 years. Finding sources proved a challenge. Unfortunately, we could not locate any company records or any correspondence on administration in Buxton. The State Historical Society of Iowa did have a major collection of photos of the town and the people who lived there, but the historical record was still rather sparse.

What we did have were the names of a number of people who had lived in Buxton or nearby. So, one more time, it was oral history to the rescue. In total, we located 75 people who had lived in Buxton or nearby. A few of the interviews were sketchy, but most were invaluable. Some of the transcripts ran to 25 pages.

When we finished recording the interviews, gathering newspaper data, reviewing the state mine inspectors' reports, processing census data, and examining various other material, I felt that we really had recreated the town of Buxton. We knew who lived there. We knew the street layouts. Given the interviews and plat maps, we could pinpoint the addresses for some of them; we could lay out the business district and the store owners. We had photos of the interior of the company store.

Beyond the basics already mentioned, Buxton was a highly unusual community in many other ways. The company did not prohibit individuals from creating privately owned businesses, and Buxton was a place where there seemed to be a high degree of racial harmony. The United Mine Workers deserved a great deal of credit for this unusual situation, as did the Consolidation Coal Company.

As with my other projects, this one produced many memorable stories and experiences. Here again, oral history was the key. But, a word of caution. Oral histories were not the only sources that were needed. Census data almost always played a big part in the projects. That was a laborious process. All the material had to be copied by hand, translated to the right numbers, and put in the right columns. Newspapers were also important. Equally laborious was the large amount of reading through reels and reels 
of microfilm. I had the feeling I was spending half of my life in the archives room at the State Historical Society of Iowa. And, once again, my dissertation experience with SPSS and statistics was crucial to the way we approached the Buxton project.

AFTER I RETIRED in 2000, I continued to write. In 2003, my book Growing Up with the Town: Family and Community on the Great Plains was published by the University of Iowa Press. Writing about the small town where my family lived and I and my siblings grew up was tremendously special to me. I also coedited the book Tradition and Transformation: A Sesquicentennial History of Iowa State University, which was published in 2007.

In reflecting on my research and writing and my time at ISU, several themes persisted: the emergence of oral history and social history, the role of luck and serendipity, and a lot of just hard work. I realize, also, that in many ways I have been very fortunate. I came of age, so to speak, when the new social history was just getting under way. And that was my forte. I also enjoyed strong institutional support. I was granted three faculty improvement leaves and also had strong backing-including release time - for another project: the history of the ISU Cooperative Extension Service. That really was equal to a faculty improvement leave.

I would also have to include the fact that the state's archives were only 30 miles away. In other words, that key resource was readily accessible. And I was tremendously fortunate to have a husband who was very proud of me and always supported my work - that was something women of my age could not always take for granted.

And, sometimes, good projects just fell into my lap. Such was the case when I received a packet of about 250 letters written by a farmer in northwest Iowa. A minister in Alaska had heard that someone at ISU was doing Iowa history. So Jim Campbell bundled up the letters - which had been written by his uncle, and mailed them to:

History Department

Iowa State University

The letters had been written in the 1920s and included a good bit of information about farm life in that era. But most significant 
was that this farmer had been a member of the Ku Klux Klan in the northwest Iowa community of Marathon. He had written often to his girlfriend in another community, and almost every letter contained something about the Klan. Sometimes the letters contained a good bit of information about the Klan. Things rarely went well with the Marathon Klan: there was constant bickering; members always seemed to be getting angry and leaving the group; plans to hold rallies rarely panned out. In many ways, it was a study in frustration or a comedy of errors. But perhaps the most important scholarly result was that the letters revealed a little-known perspective on American history; for this farmer, the KKK really served as a social organization.

There were always - always - a great variety of good topics to research. The search for significant topics in Iowa history is like the state itself. Just as the seemingly featureless expanses of prairies contain spots of great beauty - river valleys, patches of crown vetch - so, too, does the expanse of a state contain many good, researchable topics of broader significance. Diligent attention can reveal them. I must add that, through the years, Iowa history became increasingly "mainstream." More professionals were writing about Iowa politics, communities, and industries. Most noticeably, graduate students were choosing Iowa topics for their theses and dissertations.

As with any endeavor, of course, there also were obstacles. There was the near-dismissive attitude held by many historians toward the value of state history. One colleague referred to teaching Iowa history as "telling nice little stories." Another asked whether students were "breaking my door down" to take Iowa history. Well, after the first few semesters, he never asked that question again. And then there was another colleague who informed me that since he didn't do oral history, he was a better historian than I. I wanted to point out that - judging by his publication record - he didn't do much history of any kind. However, I demurred.

Looking back, what a wonderful career I have had! Perhaps most of all, I remember the people I met: Cliff Carlson, a sculptor carving a replica of the Cardiff Giant out of a huge block of Fort Dodge gypsum. The former grad student whose writing was so messy he literally couldn't tell the top of his handwritten test 
paper from the bottom. Miners and their wives. The Amish. George C. Christensen, the ISU administrator who intervened for me at a crucial time in my career. Brother Gerard, the Trappist monk with the most delightful giggle. I have been privileged to see the way state history has come of age. To be in a field where the research possibilities are endless and the research material is usually close at hand. To work in an area that provides such a personal association with history. To teach a course where students can see so clearly the way their families and their communities fit into the larger context of social and economic history. I am profoundly grateful to Ames and Iowa State University for the personal and professional lives they have given me. 